\title{
Are Women Less Likely to Ask than Men Partly Because They Work Fewer Hours? A Commentary on Artz et al. (2018)
}

\author{
Jens Mazei and Joachim Hüffmeier \\ TU Dortmund University
}

\begin{abstract}
A long debate in negotiation research concerns the question of whether gender differences in the propensity to initiate negotiations, in behaviors shown during negotiations, and in negotiation performance actually exist. Whereas past negotiation research suggested that women are less likely to initiate negotiations than men, a recent study by Artz et al. (2018) seems to suggest that women are as likely as men to "ask" for higher pay. However, this finding by Artz et al. (2018) was obtained once the number of weekly hours worked was added as a covariate in the statistical analysis. Following extant work, we suggest that the number of weekly hours worked could be-and, from a theoretical standpoint, perhaps should be-considered a mediator of gender differences. Conducting a Monte Carlo analysis based on the results and statistics provided by Artz et al. (2018) also yielded empirical evidence suggesting that weekly hours could be a mediator. Thus, women may be less likely than men to ask for higher pay, among other potential reasons, because they work fewer weekly hours. Based on this alternative conceptualization of the role of weekly hours, our commentary has theoretical implications for the understanding of gender differences in the propensity to initiate negotiations and practical implications for the effective reduction of gender inequalities.
\end{abstract}

Keywords: gender, sex, negotiation, bargaining, gender gap

Gender differences are a "hot" topic in negotiation research (e.g., Bowles et al., 2019; Small et al., 2007). This is because gender differences in the propensity to initiate negotiations as well as in negotiation behaviors and performance may help to account for longstanding inequalities (i.e., gender gaps in pay and top leadership positions; Bureau of Labor Statistics [BLS], 2019a; Catalyst, 2020; Kulik \& Olekalns, 2012; Stuhlmacher \& Walters, 1999). In fact, research has shown that women are less likely to initiate negotiations than men (for a meta-analysis, see Kugler et al., 2018). Thus, women may earn less than men, in part, as they "do not ask" (Babcock \& Laschever, 2003; Babcock et al., 2006; Bowles et al., 2007).

Yet, a recent study by Artz et al. (2018) seems to question this narrative. Our commentary focuses on one central result of this recent study, namely that women were no less likely than men to try to get higher pay. However, this result was obtained only when the number of weekly hours worked was added as a covariate (Artz et al., 2018; see also Luekemann \& Abendroth, 2018). The study by Artz et al. (2018) already had an impact: It has been cited 56 times (Google Scholar; December 15, 2020), including in prestigious outlets such as the Academy of Management Annals (Jang et al., 2018). It has also been discussed in the media as follows: "Findings seem to debunk perception that women lack assertiveness when negotiating salaries, a common explanation for wage gap" (Lartey, 2016). Therefore, the findings by Artz et al. (2018) may be taken as raising serious doubts about cumulative knowledge obtained in past negotiation research on gender. 
The key question is: Do women ask (Artz et al., 2018) or don't they (Babcock \& Laschever, 2003; Kugler et al., 2018)? In this commentary, we aim to reconcile the seemingly diverging conclusions drawn from the study by Artz et al. (2018) and past negotiation research by thoroughly embedding the findings by Artz et al. (2018) in extant theory (e.g., Bowles \& McGinn, 2008; Eagly \& Wood, 2012) and research (e.g., Luekemann \& Abendroth, 2018). Doing so suggests an alternative interpretation of the findings by Artz et al. (2018), which has markedly different theoretical and practical implications: Women may not ask, among other potential reasons, because they work fewer hours than men (see also Bowles \& McGinn, 2008; Livingston, 2014; Luekemann \& Abendroth, 2018). This alternative interpretation has not only nuanced theoretical implications, but also practical implications for the successful mitigation of gender inequalities.

\section{Background in Brief}

To start, we would like to clarify the terms "sex" and "gender" as used in the current commentary. In psychological science, "sex" is usually used to "refer to male, female, and intersex as categories or groups of people" (Bosson et al., 2018, p. 6), whereas "gender" is usually used to "refer to the meanings that people give to the different sex categories" (Bosson et al., 2018, p. 6). For example, if women had a lower propensity to initiate negotiations than men, this finding could be denoted as a "sex difference" (e.g., Wood \& Eagly, 2002). However, in the current area of research (i.e., negotiations), it is more common to denote such effects as "gender differences" (e.g., Bowles et al., 2007; Kugler et al., 2018). Hence, to ease communication in the specific area of research to which we aim to contribute, we adhere to the consensus in negotiation research and use the term "gender."

Negotiation research on gender dates back to at least the 1970s (Rubin \& Brown, 1975; cf. Kray \& Thompson, 2005; Small et al., 2007). From early on, a key question was whether women actually differ from men. Given that findings were often mixed (Stuhlmacher \& Walters, 1999; Walters et al., 1998), and given that (psychological) research generally has long been characterized by low statistical power (Cohen, 1992; Maxwell, 2004), meta-analysis plays a crucial role in determining whether gender differ- ences exist in behaviors and outcomes related to negotiations (see also Eagly \& Wood, 2013). Meta-analyses revealed small yet significant gender differences, such that women as compared to men show less competitive negotiation behavior (Walters et al., 1998), obtain lower economic outcomes (Mazei et al., 2015; Shan et al., 2019; Stuhlmacher \& Walters, 1999), and, of particular relevance for this commentary, are less likely to initiate negotiations (Kugler et al., 2018).

\section{The Study by Artz et al. (2018)}

A recent study by Artz et al. (2018) seems to raise doubts about central findings from past research, as it "concludes that males and females ask equally often for promotions and raises" (p. 611). We would like to make clear from the outset that we appreciate the work by Artz et al. (2018), as their study provides noteworthy results that have generated renewed interest in the question of whether (and why) women actually differ from men in the propensity to initiate negotiations. As we will highlight in this commentary, their study also sparks needed discussion specifically about the role played by the number of weekly hours worked for the emergence of gender differences in the propensity to initiate negotiations (see also Luekemann \& Abendroth, 2018). However, care needs to be taken if findings can be interpreted other than "males and females ask equally often" (Artz et al., 2018, p. 611). A notable alternative interpretation could be that women did no longer differ from men when a mediator was included in the analysis (for details, see below). If such an alternative interpretation is not considered, important lessons learned from past negotiation research (i.e., there are real gender differences in negotiation contexts; Kugler et al., 2018) might become obscured, and practitioners might not implement interventions that are actually needed (e.g., those that address the flexibility stigma; Williams et al., 2013; see also below). Thus, our goal is to suggest an alternative interpretation, based on extant work (e.g., Bowles \& McGinn, 2008; Eagly \& Wood, 2012), of the findings by Artz et al. (2018).

Artz et al. (2018) examined a representative sample of $N=4,582$ employees from Australia $(n=2,639$ women and $n=1,943$ men) to test at least two notions that are prominent in extant negotiation research on gender. These were (a) that "women may be reluctant to 'ask,' because that might be viewed 


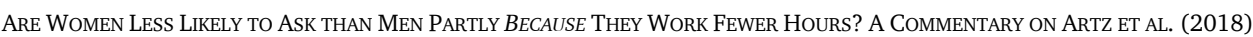

by their manager as pushy or 'out-of-role' behavior for a female," and (b) that "in certain circumstances, women may have a lower propensity than men to ask for pay raises and promotions" (Artz et al., 2018, p. 611). The authors obtained many interesting findings, some of which that were inconsistent with past research, or at least they were interpreted as such (for our alternative interpretation, see below). Women were not more likely than men to be concerned about straining the relationship with others as a result of trying to get higher pay or a promotion (Artz et al., 2018). This result is in line with the prominent research by Bowles et al. (2007), but not with the likewise prominent research by Amanatullah and Morris (2010) and Babcock et al. (2006). This result does not support the notion that women are afraid to come across as "pushy" (Amanatullah \& Tinsley, 2013).

Furthermore, women were not found to differ from men in analyses on a variable tapping into the propensity to ask for a promotion (irrespective of which covariates were included; Artz et al., 2018). This finding does not suggest a gender difference in the decision to initiate negotiations about career advancement (Luekemann \& Abendroth, 2018). Yet women were less likely than men to indicate having had success in negotiating pay (Artz et al., 2018), which is in line with another longstanding notion in negotiation research on gender (cf. Stuhlmacher \& Walters, 1999). This noteworthy result led Artz et al. (2018, p. 629) to conclude that "females are less successful at getting," although they might not be less inclined to ask. The distinction between gender differences in "asking" and "getting" is relevant, for instance, because the two phenomena would suggest different interventions (see the section on Implications for Practice below).

Being the focus of our commentary, Artz et al. (2018) also examined the likelihood with which women and men attempted to get higher pay(rather than a promotion; see above). This criterion is especially relevant because asking for higher pay is a direct way to reduce the gender pay gap. Women were less likely than men to have attempted to get higher pay in two regressions that included several covariates (Artz et al., 2018). However, this gender difference became non-significant once the number of weekly hours worked was included as an additional covariate (for further analyses on full-time and parttime workers, see Table 4 in Artz et al., 2018; see also Luekemann \& Abendroth, 2018; Stevens \& Whelan, 2019). As the authors noted (p. 623), "on closer scrutiny, the appearance of a lack of 'asking' is being driven statistically by working fewer hours." The number of weekly hours worked was, in fact, positively related to the likelihood of having attempted to get higher pay. In their conclusions, Artz et al. (2018, pp. 628-629) again stressed that "this adjustment for hours is particularly important. Once it is done, regression equations for the likelihood of 'asking' do not show a statistically significant difference between men and women." The number of weekly hours worked clearly played an important role in the study by Artz et al. (2018).

\section{What is the Conceptual Role of Weekly Hours?}

The findings by Artz et al. (2018) may be interpreted such that women "do ask," and this seems to be the favored interpretation by the authors. However, in the case of asking for higher pay, this interpretation only holds true if the conceptual role of the number of weekly hours worked is a covariate (or control variable/confounder; MacKinnon et al., 2000). Artz et al. (2018, p. 629) noted: "Our results have concentrated on the case in which hours of work are held constant. This is arguably natural, because we wish here to do a ceteris paribus comparison between males and females, but we have not attempted to explain the observed difference in the mean number of working hours between men and women" (in Footnote 10, the authors additionally hinted that "these differences in working hours presumably stem in part from historical and sociological differences in the gender roles").

Given the relevance of the number of weekly hours in the study by Artz et al. (2018), we argue that a deepened elaboration on its conceptual role is in order (see also Luekemann \& Abendroth, 2018). Doing so strikes us as important because the results obtained by Artz et al. (2018) suggest that the number of weekly hours could also be a mediator. Artz et al. (2018) did not more closely examine the gender difference in weekly hours-the $a$-path in a mediation-but their reported statistics allowed us to do so. Women $(M=33.87, S D=10.43)$ worked significantly fewer weekly hours than men $(M=41.60, S D$ $=9.86), t(4,580)=25.37, p<.001$. This gender differ ence had an effect size of $d=0.76$ (calculated on the basis of the unrounded numbers given by Artz et al., 2018, and formulas 12.11 and 12.12 given by Borenstein, 2009, p. 226). As mentioned above, weekly hours were also significantly related to the likelihood of having attempted to get higher pay (while controlling for gender; see Table 3, Equation 9 in 
Artz et al., 2018). This finding suggests a significant $b$-path (see also Baron \& Kenny, 1986). Following the logic of a joint-significance test (see also the component approach in Yzerbyt et al., 2018), this pattern of results could be interpreted as suggesting mediation. As Kenny (2018) put it, "if Step 2 (the test of a) and Step 3 (the test of $b$ ) are met, it follows that the indirect effect is likely nonzero."

To examine a potential indirect effect through weekly hours, we also conducted a Monte Carlo analysis using Selig and Preacher's tool (2008; see also Preacher \& Selig, 2012). The results are displayed in Figure 1. The analysis, based on 20,000 repetitions, yielded a $95 \%$ confidence interval (CI) for the indirect effect that ranged from 0.02 to 0.04-thus, it did not include zero. This finding again suggests a significant indirect effect through weekly hours. Taken together, statistically speaking, the number of weekly hours could be seen as a covariate (in MacKinnon et al.'s, 2000, terms, a "confounder") or as a mediator.

Figure 1

Monte Carlo analysis of an indirect effect.

\section{Distribution of Indirect Effect}

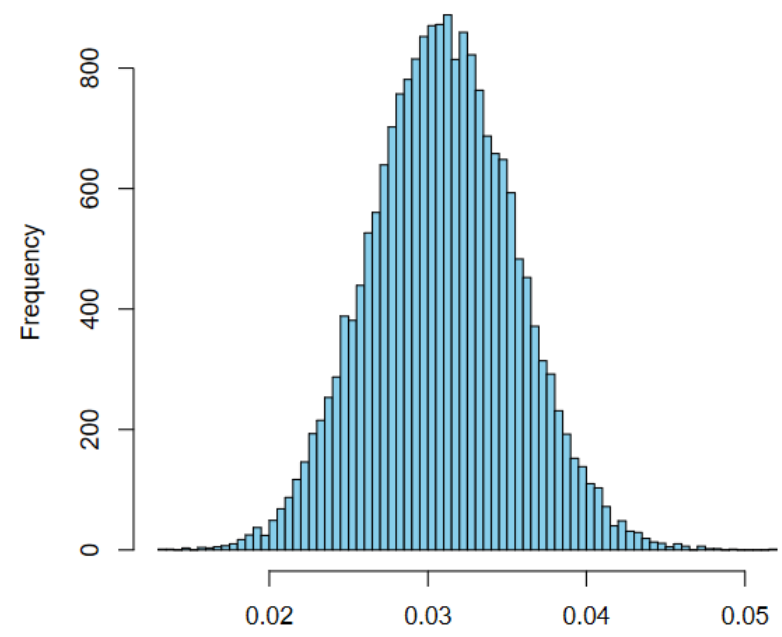

95 \% Confidence Interval LL 0.02214 UL 0.04004

Note. This analysis was conducted using Selig and Preacher's tool (2008; see also Preacher \& Selig, 2012). The figure shows the distribution of estimations of the indirect effect (i.e., $a \times b$ ). The resulting 95\% CI excludes zero, suggesting an indirect effect through weekly hours.

Given this lack of clarity regarding the conceptual role of weekly hours, our goal is to embed the findings by Artz et al. (2018) in extant theory (e.g.,
Bowles \& McGinn, 2008; Eagly \& Wood, 2012) to begin disentangling their conceptual role. Theory explains "why empirical patterns were observed" (Sutton \& Staw, 1995, p. 374; see also Bacharach, 1989; Whetten, 1989) and provides hypotheses regarding the specific conceptual roles played by constructs of interests. Nevertheless, as the question of whether weekly hours is a mediator or a covariate is a question about the causal influence of weekly hours, suitable empirical methods that test for causality with longitudinal studies are also needed. Below, we report relevant empirical work (e.g., Luekemann \& Abendroth, 2018), yet focused longitudinal studies on this topic are currently missing. Thus, as it stands, weekly hours only have the potential to be a mediator of the gender difference in the likelihood with which salary negotiations are initiated, and additional research is needed (see the section on Implications for Theory and Future Research).

\section{Why Weekly Hours Could Be a Mediator (Among Others)}

Current negotiation research on gender is often grounded in social role theory (Eagly, 1987; Eagly \& Wood, 2012) and the related role congruity theory (Eagly \& Karau, 2002), as this framework proved helpful to integrate extant research (e.g., Amanatullah \& Morris, 2010; Kugler et al., 2018; Stuhlmacher \& Linnabery, 2013). Artz et al. (2018) referred to but did not elaborate on these theories. In Figure 2, we depict a simplified model adapted from Eagly and Wood's (2012) framework (see Figure 49.1 in Eagly \& Wood, 2012, p. 465, for their framework in its original form). The aim of the model shown in Figure 2 is to explain gender differences in the propensity to initiate negotiations about salary (see Path 1). In a nutshell, women may be less likely to initiate salary negotiations, among other reasons, because they work fewer weekly hours, which is one aspect of the division of labor (see Paths 2 and 3; Bowles \& McGinn, 2008; Eagly et al., 2020; Luekemann \& Abendroth, 2018). In addition, the division of labor leads to the emergence of gender roles (Path 4; Eagly \& Steffen, 1984; Koenig \& Eagly, 2014), which can also drive gender differences (Path 5; Kugler et al., 2018; Stuhlmacher \& Linnabery, 2013). We now elaborate on these notions. 
ARe Women Less Likely to AsK than Men PARtLy BeCAUSE They Work FeWer Hours? A Commentary on ARTZ ET AL. (2018)

\section{Division of Labor: Women Work Fewer Hours than Men}

A first key notion in the underlying framework by Eagly and Wood (2012; see also Eagly, 1987) that is relevant for our research is that there is often a $d i^{-}$ vision of labor among women and men. As Eagly et al. (2020, p. 302) pointed out, "a common arrangement is a neotraditional division of labor": Women as compared to men spend less time at work-that is, they have fewer weekly hours of paid work (see Path 2 in Figure 2)-but more time on household and caretaking activities (e.g., BLS, 2019b; Eagly \& Carli,
2007). In fact, women in the United States, and also in many other Western countries, are more likely than men to work part-time; and this gender difference can be observed across different age groups and ethnicities (BLS, 2018). In the representative sample examined by Artz et al. (2018), women also worked significantly fewer hours than men $(d=$ 0.76). Altogether, the observation that women work fewer hours than men is an important aspect of the division of labor (e.g., Eagly \& Wood, 2012). In other words, a division of labor means (in part) that women and men differ in their weekly hours of paid work (see Path 2 in Figure 2).

Figure 2

Mediation of gender differences in the propensity to initiate salary negotiations.

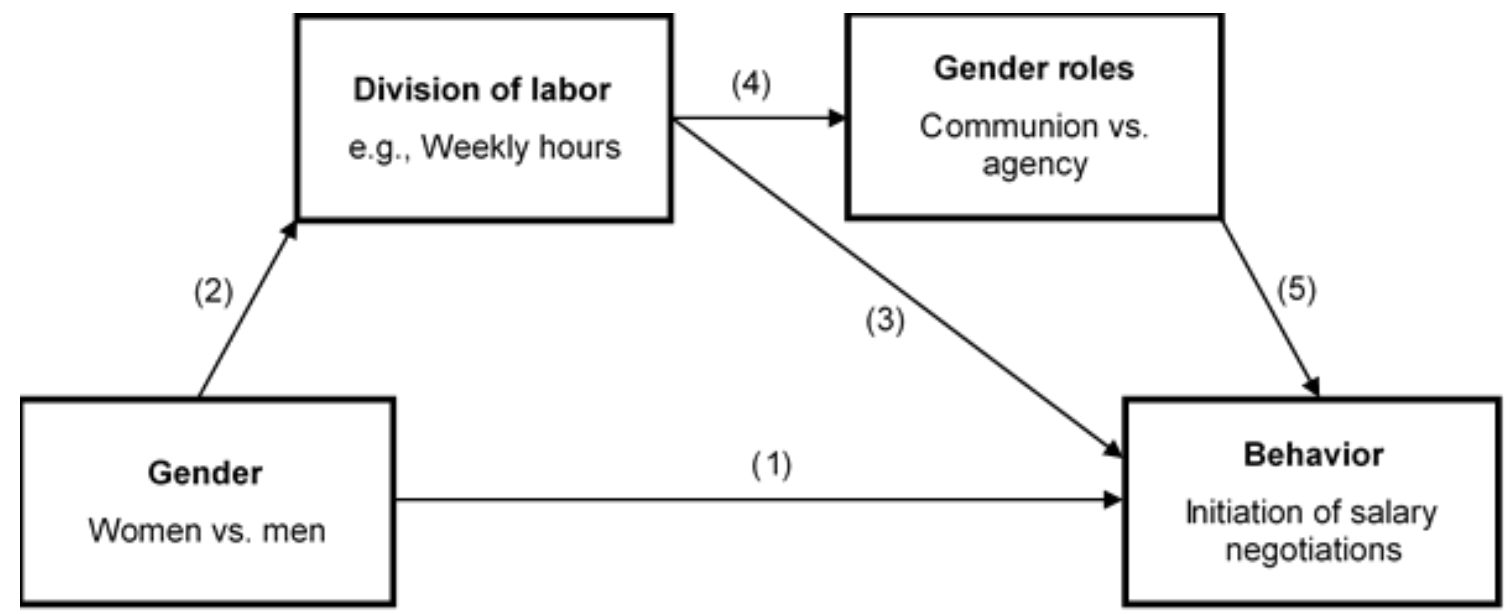

Note. This figure shows a simplified and adapted model that follows from Eagly and Wood's (2012) framework. The model shown here is simplified because Eagly and Wood's (2012) framework entails additional constructs and processes (e.g., socialization) that are beyond the scope of our research. The model shown here is adapted, most notably, because we highlight those aspects (e.g., weekly hours of paid work) that are most relevant for our research and also because Eagly and Wood's (2012) figure does not include a box for "gender" (i.e., women vs. men). However, visualizing the relationship between gender and weekly hours (Path 2) makes explicit the notion that the division of labor entails, among other aspects, a gender difference in weekly hours (e.g., Eagly et al., 2020). For a figure of the underlying framework in its original form, see Eagly and Wood (2012, p. 465). 
The gender difference in weekly hours is not the only aspect of the division of labor (e.g., women and men often work in different types of occupations; Eagly et al., 2020). Moreover, different aspects of the division of labor can influence each other: A prime example is that having (more) caretaking duties makes it more difficult to pursue other (workplace) activities (e.g., Eagly \& Carli, 2007; Wood \& Eagly, 2012). Yet, we focus on weekly hours because this was the decisive variable in the study by Artz et al. (2018): Controlling for weekly hours rendered the gender difference in the likelihood to ask about pay non-significant, and this particular result led to their conclusion that women "do ask" (Artz et al., 2018). This does not mean, however, that other variables (e.g., tenure; see Table 3 in Artz et al., 2018) are irrelevant for gender differences to emerge. Thus, it is appropriate to regard weekly hours as only one potential mediator of gender differences in the likelihood to negotiate salary (see also Bowles \& McGinn, 2008; Luekemann \& Abendroth, 2018).

\section{The Division of Labor has Consequences for the In- itiation of Salary Negotiations}

The division of labor has many structural and psychological consequences (Eagly \& Wood, 1999). That is, working fewer hours not only reduces one's pay as a structural consequence (e.g., Eagly \& Carli, 2007; Eagly \& Wood, 2012), it can also yield a flexibility stigma (Williams et al., 2013) as a psychological consequence. This stigma is defined as "a type of discrimination triggered whenever an employee signals a need for workplace flexibility due to family responsibilities (e.g., by requesting leaves of absence or flexible hours)" (Rudman \& Mescher, 2013, p. 323; see also Chung, 2020). This is because working reduced or flexible hours can be viewed as an indication of lacking work devotion ${ }^{1}$ (e.g., Bourdeau et al., 2019; Williams et al., 2013). Of greater relevance for our research, however, are people's own perceptions, not just other's discriminatory reactions (i.e., another psychological consequence): If people work reduced or flexible hours, they may deem themselves as lacking work devotion, so that they may not feel entitled or consider it appropriate to receive higher pay (for literature on entitlement, see Major, 1989). This is because "the work devotion schema is [...] seductive-workers may also believe that a

1 The work devotion schema "reflects deep cultural assumptions that work demands and deserves undivided and intensive allegiance" (Williams et al., 2013, p. 211). strong work ethic helps form their sense of self and self-worth" (Williams et al., 2013, p. 211). Thus, if people do not consider it appropriate to receive higher pay, they should be unlikely to ask for it (Bowles \& McGinn, 2008; Luekemann \& Abendroth, 2018).

Altogether, as women work fewer hours than men given the extant division of labor (Path 2 in Figure 2; BLS, 2018), they may be less likely to initiate negotiations about salary-a relationship visualized as Path 3 in Figure 2 (see also Bowles \& McGinn, 2008, which is described in detail below, and Livingston, 2014). As mentioned earlier, Artz et al.'s (2018) study suggested a positive relationship between weekly hours and the likelihood with which people attempted to get higher pay (for a similar result, see Stevens \& Whelan, 2019). Notably, Luekemann and Abendroth (2018) also found that women with children (vs. men with children) were less likely to initiate a discussion about career advancement, and this gender difference became non-significant once working hours (as well as overtime hours and tenure) were included as additional covariates (see their Model 4 on pp. 16-17 and their Footnote 4). Although Luekemann and Abendroth (2018) did not study people's propensity to negotiate pay, their findings were conceptually and empirically similar to those obtained by Artz et al. (2018). Thus, Luekemann and Abendroth (2018, p. 17) similarly noted that "mothers' lower likelihood to pose claims is mainly driven by them working fewer hours." Moreover, we conducted an own (unpublished) study with a crosssectional design (Mazei, Nohe, \& Hüffmeier, 2017). We observed, for instance, that women as compared to men reported being more responsible for homemaking duties but less for being the breadwinner. In turn, being responsible for homemaking duties was positively related to working part-time, but negatively related to the frequency with which negotiations about pay were initiated.

\section{The Division of Labor Causes Gender Roles, Which also Drive Gender Differences}

The division of labor is relevant (cf. Bowles \& McGinn, 2008) in still another respect, as it causes gender roles (e.g., Eagly \& Steffen, 1984; Eagly \& Wood, 1999), defined as "consensual [and normative] beliefs about the attributes of women and men" 


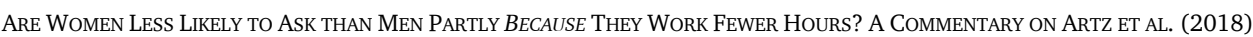

(Eagly \& Karau, 2002, p. 574; Eagly, 1987). This relationship is shown as Path 4 in Figure 2 (Eagly \& Wood, 2012; see also Koenig \& Eagly, 2014). Negotiation research has devoted great attention to gender roles because initiating negotiations fits men's agentic gender role, but not women's communal gender role (e.g., Kugler et al., 2018; Stuhlmacher \& Linnabery, 2013; see also Eagly \& Karau, 2002). Given this misfit among women, people react more negatively toward women who initiate negotiations (Bowles et al., 2007) and negotiate in an agentic manner (Amanatullah \& Tinsley, 2013; regarding such negative reactions, see also Rudman et al., 2012). Thus, gender roles also play a role in the emergence of gender differences in the propensity to initiate negotiations (e.g., Kugler et al., 2018), as depicted as Path 5 in Figure 2.

Another relevant notion in the literature is that "gender roles coexist with specific roles based on factors such as family relationships and occupation" (Eagly \& Wood, 1999, p. 413), and gender roles and aspects of the division of labor may have partially independent effects in certain settings. For instance, Eagly and Wood (2012, p. 469, emphasis added) noted that "because specific roles have direct implications for task performance in many natural settings, they can be more important than gender roles." In other words, the division of labor can drive gender differences not only because it causes gender roles (e.g., Eagly \& Steffen, 1984), which is why Figure 2 includes Path 3 (see the rationale above and the general notion of "constraints" below; Bowles \& McGinn, 2008; Eagly \& Wood, 1999). Conversely, gender roles can lead to gender differences even if a current division of labor is controlled for (Eagly, 1987; Eagly \& Wood, 1999). This is possible, for instance, because people might have learned gender roles earlier in their lives, which then keep affecting their own and other's actions even in the absence of a current division of labor (Eagly \& Wood, 1999; 2012). This insight is notable because it explains why gender differences can emerge in laboratory settings in which the division of labor with its usual constraints (Eagly \& Wood, 1999) is less relevant, as was highlighted by Eagly (1987). As previously learned gender roles can have an independent effect in a current setting, it may again be appropriate to regard weekly hours as one mediator (potentially among others).

\section{Altogether, Weekly Hours Could be a Mediator}

Observing a null effect for gender while controlling for weekly hours or other aspects of the division of labor-as was the case in Artz et al. (2018)-can be interpreted in different ways. On the one hand, such a null effect could mean that there simply is no gender difference. On the other hand, it could mean that gender differences in the propensity to initiate salary negotiations are not solely driven by gender roles, but also by those aspects of the division of labor that were controlled for. Extant work (e.g., Eagly \& Wood, 1999; Luekemann \& Abendroth, 2018) suggests that the latter possibility could be true. Thus, weekly hours could be-and, from a theoretical standpoint, perhaps should be-considered a mediator.

All told, the division of labor is a central construct that can help to explain why gender differences in the propensity to initiate negotiations, and in many other contexts, exist (e.g., Eagly \& Wood, 1999; Luekemann \& Abendroth, 2018). For instance, working fewer hours not only gives rise to the hampering flexibility stigma (e.g., Williams et al., 2013), but gender roles, which exist due to the division of labor (e.g., Eagly \& Steffen, 1984), also create obstacles for women in negotiation contexts (e.g., Stuhlmacher \& Linnabery, 2013). These insights were succinctly pointed out by Bowles and McGinn (2008): They described gender dynamics as a "two-level game," such that negotiations at work are related to negotiations at home (see also Livingston, 2014). As they put it (p. 395), "the traditional division of labor between the sexes - in which men are the breadwinners and women are the caregivers - creates asymmetries between men and women in terms of how constrained their negotiations with employers (at Level One) are by their negotiations with household members (at Level Two)." Thus, women may be less likely to ask about higher pay because they work fewer weekly hours (cf. Luekemann \& Abendroth, 2018).

\section{Implications for Theory and Future Research}

If the number of weekly hours worked were a mediator, the findings by Artz et al. (2018) should no longer be interpreted as contradicting past negotiation research (e.g., Babcock \& Laschever, 2003; Kugler et al., 2018). Interpreting their results such that women did not ask, among other reasons, because they work fewer hours would suggest the existence 
of a gender difference, just as past research did. What may be different about the findings by Artz et al. (2018), however, is the specific process that drives the gender difference. Past research typically focused on the effects of gender roles (see Path 5 in Figure 2; e.g., Amanatullah \& Morris, 2010; Stuhlmacher \& Linnabery, 2013). Gender roles result from the division of labor (see Path 4 in Figure 2; Eagly \& Wood, 2012; Koenig \& Eagly, 2014), yet they can drive gender differences on their own in certain contexts (see above; Eagly, 1987; Eagly \& Wood, 1999). Thus, if the goal of a study is to isolate the potential effects of gender roles, it can make sense to control for aspects of the division of labor, such as weekly hours. Thus, if a study pursues this goal, weekly hours could also be conceptualized as a covariate.

Alternatively, the results by Artz et al. (2018) may suggest that weekly hours-an aspect of the division of labor-mediate gender differences in the propensity to initiate negotiations (see Paths 2 and 3 in Figure 2). Thus, the division of labor may drive gender differences in the context of negotiations in different ways, and not "only" through gender roles (Paths 4 and 5 in Figure 2; see also Bowles \& McGinn, 2008; Luekemann \& Abendroth, 2018). Altogether, the seemingly diverging conclusions drawn from past research and Artz et al. (2018) can be reconciled by the theoretical argumentation presented here.

Some studies have already shed first light on the potential relevance of weekly hours for the emergence of gender differences in negotiation contexts (e.g., Luekemann \& Abendroth, 2018; and, of course, the study by Artz et al., 2018). Yet, additional negotiation research that sheds a brighter light on the role of weekly hours, and the division of labor, more generally, is clearly needed. Suggesting that weekly hours could be a mediator entails that evidence of its causal effects is needed. Please note, however, that conducting "true" experiments, in which the division of labor among women and men is manipulated, is not possible. Thus, a particularly worthwhile avenue for future research would be to conduct longitudinal studies. These studies could examine whether changes in the division of labor help to explain gender differences in the propensity to initiate salary negotiations. This future research will help to determine whether the number of weekly hours not only has the potential to be a mediator, but actually is one.

\section{Implications for Practice}

An alternative interpretation of the findings by Artz et al. (2018) would go hand in hand with alternative practical implications. If women were only "less successful at getting" (Artz et al., 2018, p. 629), practical interventions would "only" need to make sure that decision-makers grant women's requests as often and as much as men's. It is clear that decision-makers should treat women and men equally, because not doing so would be blatant discrimination. However, this intervention on its own is unlikely to be sufficient if women were less likely than men to "ask" in the first place. As the division of labor may drive gender differences in negotiation contexts and beyond (see Path 3 in Figure 2; e.g., Bowles \& McGinn, 2008; Eagly \& Wood, 2012), more might need to be done to eliminate gender differences. In the long term, for gender differences to diminish, women and men would need to share breadwinning and caretaking duties more equally (but see Croft et al., 2015, who highlighted that men typically fulfill caretaking duties to a lesser extent than women). In the short term, interventions to reduce the flexibility stigma (e.g., Williams et al., 2013) would also help. Specifically, supportive organizational norms can mitigate perceptions of low work devotion among people who work fewer hours and the related negative consequences (Bourdeau et al., 2019). These additional interventions should help to encourage women to "ask" with the same likelihood and as much as men do (Luekemann \& Abendroth, 2018).

\section{Conclusion}

Gender differences remain a "hot" topic in negotiation research. Artz et al. (2018) provided valuable and noteworthy findings that have stimulated anew the debate whether or not (and why) women and men differ in the propensity to initiate negotiations. Given that they interpreted their results such that they question cumulative knowledge obtained in past negotiation research, it is crucial to carefully scrutinize the results and their interpretation. As we highlighted in our commentary, following extant work (e.g., Bowles \& McGinn, 2008; Eagly \& Wood, 2012), weekly hours could be one notable mediator of gender differences in the propensity to initiate salary negotiations. This possibility is relevant because, thus far, "negotiation scholars have largely ignored the structural implications of job candidates' 


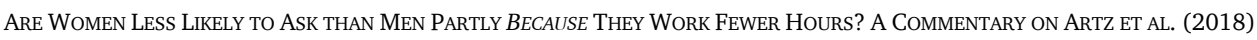

domestic relations when studying negotiations with employers" (Bowles \& McGinn, 2008, pp. 394-395; but see Luekemann \& Abendroth, 2018). Thus, future negotiation research should devote greater attention to weekly hours and examine further their potential relevance for the emergence of gender differences in negotiation contexts.

\section{Author Contact}

Jens Mazei, Department of Psychology, TU Dortmund University, https://orcid.org/0000-00033579-6857; Joachim Hüffmeier, Department of Psychology, TU Dortmund University, https://orcid.org/0000-0002-0490-7035. Correspondence concerning this article should be addressed to Jens Mazei, Department of Psychology, TU Dortmund University, Emil-Figge-Straße 50, 44227 Dortmund, Germany.E-mail: jens.mazei@tu-dortmund.de

\section{Conflict of Interest and Funding}

We declare that we do not have any conflicts of interests that might be interpreted as influencing this commentary. We have not received any specific funding for this research.

\section{Author Contributions}

Jens Mazei developed the concept for this commentary and drafted the manuscript. Joachim Hüffmeier provided comments on the manuscript and edited it. The author names order reflects the different contributions by the authors.

\section{Open Science Practices}

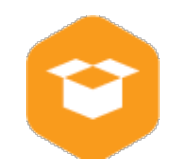

This article earned the Open Materials badge for making the materials openly available. This is a commentary on another study and as such did not produce new data and was not pre-registered. It has been verified that the analysis reproduced the results presented in the article. The entire editorial process, including the open reviews, is published in the online supplement.
References

Amanatullah, E. T., \& Morris, M. W. (2010). Negotiating gender roles: Gender differences in assertive negotiating are mediated by women's fear of backlash and attenuated when negotiating on behalf of others. Journal of Personality and Social Psychology, 98(2), 256-267. https://doi.org/10.1037/a0017094

Amanatullah, E. T., \& Tinsley, C. H. (2013). Punishing female negotiators for asserting too much...or not enough: Exploring why advocacy moderates backlash against assertive female negotiators. Organizational Behavior and Human Decision Processes, 120(1), 110-122. https://doi.org/10.1016/j.obhdp.2012.03.006

Artz, B., Goodall, A. H., \& Oswald, A. J. (2018). Do women ask? Industrial Relations, 57(4), 611-636. https://doi.org/10.1111/irel.12214

Babcock, L., \& Laschever, S. (2003). Women don't ask: Negotiation and the gender divide. Princeton, NJ: Princeton University Press.

Babcock, L., Gelfand, M. J., Small, D. A., \& Stayn, H. (2006). Gender differences in the propensity to initiate negotiations. In D. De Cremer, M. Zeelenberg, \& J. K. Murnighan (Eds.), Social psychology and economics (pp. 239-259). Mahwah, NJ: Lawrence Erlbaum Associates Publishers.

Bacharach, S. B. (1989). Organizational theories: Some criteria for evaluation. Academy of Management Review, 14(4), 496-515.

https://doi.org/10.5465/amr.1989.4308374

Baron, R. M., \& Kenny, D. A. (1986). The moderatormediator variable distinction in social psychological research: Conceptual, strategic, and statistical considerations. Journal of Personality and Social Psychology, 51(6), 1173-1182.

https://doi.org/10.1037/0022-3514.51.6.1173

Bear, J. B., \& Glick, P. (2017). Breadwinner bonus and caregiver penalty in workplace rewards for men and women. Social Psychological and Personality Science, 8(7), 780-788. https://doi.org/10.1177/1948550616683016

Borenstein, M. (2009). Effect sizes for continuous data. In H. Cooper, L. V. Hedges, \& J. C. Valentine (Eds.), Handbook of research synthesis and metaanalysis (2nd ed., pp. 221-235). New York, NY: Russell Sage Foundation.

Bosson, J. K., Vandello, J. A., \& Buckner, C. E. (2018). The psychology of sex and gender. Thousand Oaks, CA: Sage. 
Bourdeau, S., Ollier-Malaterre, A., \& Houlfort, N. (2019). Not all work-life policies are created equal: Career consequences of using enabling versus enclosing work-life policies. Academy of Management Review, 44(1), 172-193. https://doi.org/10.5465/amr.2016.0429

Bowles, H. R., Babcock, L., \& Lai, L. (2007). Social incentives for gender differences in the propensity to initiate negotiations: Sometimes it does hurt to ask. Organizational Behavior and Human Decision Processes, 103(1), 84-103. https://doi.org/10.1016/j.obhdp.2006.09.001

Bowles, H. R., \& McGinn, K. L. (2008). Gender in job negotiations: A two-level game. Negotiation Journal, 24(4), 393-410.

https://doi.org/10.1111/j.15719979.2008.00194.x

Bowles, H. R., Thomason, B., \& Bear, J. B. (2019). Reconceptualizing what and how women negotiate for career advancement. Academy of Management Journal, 62(6), 1645-1671. https://doi.org/10.5465/amj.2017.1497

Bureau of Labor Statistics (2018). Who chooses parttime work and why? Retrieved April, 8, 2020, from www.bls.gov/opub/mlr/2018/article/whochooses-part-time-work-and-why.htm

Bureau of Labor Statistics (2019a). Highlights of women's earnings in 2018. Retrieved December, 6, 2019, from www.bls.gov/opub/reports/womensearnings/2018/pdf/home.pdf

Bureau of Labor Statistics (2019b). American time use survey - 2018 results. Retrieved April, 6, 2020, from www.bls.gov/news.release/pdf/atus.pdf

Catalyst (2020). Pyramid: Women in S\&P 500 Companies. Retrieved March, 25, 2020, from www.catalyst.org/research/women-in-sp-500-companies/

Chung, H. (2020). Gender, flexibility stigma and the perceived negative consequences of flexible working in the UK. Social Indicators Research, 151(2), 521-545. https://doi.org/10.1007/s11205-0182036-7

Cohen, J. (1992). A power primer. Psychological Bulletin, 112(1), 155-159. https://doi.org/10.1037/0033-2909.112.1.155

Croft, A., Schmader, T., \& Block, K. (2015). An underexamined inequality: Cultural and psychological barriers to men's engagement with communal roles. Personality and Social Psychology Review, 19(4), 343-370.

https://doi.org/10.1177/1088868314564789

Eagly, A. H. (1987). Sex differences in social behavior: A social-role interpretation. Hillsdale, NJ: Lawrence Erlbaum Associates, Inc.

Eagly, A. H., \& Carli, L. L. (2007). Through the labyrinth: The truth about how women become leaders. Boston, MA: Harvard Business School Press.

Eagly, A. H., \& Karau, S. J. (2002). Role congruity theory of prejudice toward female leaders. Psychological Review, 109(3), 573-598. https://doi.org/10.1037/0033-295X.109.3.573

Eagly, A. H., Nater, C., Miller, D. I., Kaufmann, M., \& Sczesny, S. (2020). Gender stereotypes have changed: A cross-temporal meta-analysis of US public opinion polls from 1946 to 2018. American Psychologist, 75(3), 301-315. https://dx.doi.org/10.1037/amp0000494

Eagly, A. H., \& Steffen, V. J. (1984). Gender stereotypes stem from the distribution of women and men into social roles. Journal of Personality and Social Psychology, 46(4), 735-754. https://doi.org/10.1037/0022-3514.46.4.735

Eagly, A. H., \& Wood, W. (1999). The origins of sex differences in human behavior: Evolved dispositions versus social roles. American Psychologist, 54(6), 408-423. https://doi.org/10.1037/0003066X.54.6.408

Eagly, A. H., \& Wood, W. (2012). Social role theory. In P. A. M. van Lange, A. W. Kruglanski, \& E. T. Higgins (Eds.), Handbook of theories of social psychology (pp. 458-476). Thousand Oaks, CA: Sage Publications.

Eagly, A. H., \& Wood, W. (2013). The nature-nurture debates: 25 years of challenges in understanding the psychology of gender. Perspectives on Psychological Science, 8(3), 340-357. https://doi.org/10.1177/1745691613484767

Jang, D., Elfenbein, H. A., \& Bottom, W. P. (2018). More than a phase: Form and features of a general theory of negotiation. Academy of Management Annals, 12(1), 318-356. https://doi.org/10.5465/annals.2016.0053

Kenny, D. A. (2018). Mediation. Retrieved December, 17, 2020, from http://davidakenny.net/cm/mediate.htm

Koenig, A. M., \& Eagly, A. H. (2014). Evidence for the social role theory of stereotype content: Observations of groups' roles shape stereotypes. Journal of Personality and Social Psychology, 107(3), 371392. https://doi.org/10.1037/a0037215

Kray, L. J., \& Thompson, L. L. (2005). Gender stereotypes and negotiation performance: An examination of theory and research. In B. M. Staw \& R. M. 
ARE Women Less Likely to AsK than Men PARTLy BeCAUSE They Work FeWER Hours? A Commentary on ARTZ ET AL. (2018)

Kramer (Eds.), Research in organizational behavior: An annual series of analytical essays and critical reviews (Vol. 26, pp. 103-182). New York, NY: Elsevier Science/JAI Press.

Kugler, K. G., Reif, J. A. M., Kaschner, T., \& Brodbeck, F. C. (2018). Gender differences in the initiation of negotiations: A meta-analysis. Psychological Bulletin, 144(2), 198-222. https://doi.org/10.1037/bul0000135

Kulik, C. T., Olekalns, M. (2012). Negotiating the gender divide: Lessons from the negotiation and organizational behavior literatures. Journal of Management, 38(4), 1387-1415.

https://doi.org/10.1177/0149206311431307

Lartey, J. (2016). Women ask for pay increases as often as men but receive them less, study says. Retrieved March, 31, 2020, from www.theguardian.com/world/2016/sep/05/gender-wage-gapwomen-pay-raise-men-study

Livingston, B. A. (2014). Bargaining behind the scenes: Spousal negotiation, labor, and work-family burnout. Journal of Management, 40(4), 949977. https://doi.org/10.1177/0149206311428355

Luekemann, L., \& Abendroth, A.-K. (2018). Women in the German workplace: What facilitates or constrains their claims-making for career advancement? Social Sciences, 7(11), 214. https://doi.org/10.3390/socsci7110214

MacKinnon, D. P., Krull, J. L., \& Lockwood, C. M. (2000). Equivalence of the mediation, confounding and suppression effect. Prevention Science, 1(4), 173-181. https://doi.org/10.1023/A:1026595011371

Major, B. (1989). Gender differences in comparisons and entitlement: Implications for comparable worth. Journal of Social Issues, 45(4), 99-115. https://doi.org/10.1111/j.15404560.1989.tb02362.x

Maxwell, S. E. (2004). The persistence of underpowered studies in psychological research: Causes, consequences, and remedies. Psychological Methods, 9(2), 147-163. https://doi.org/10.1037/1082-989X.9.2.147

Mazei, J., Hüffmeier, J., Freund, P. A., Stuhlmacher, A. F., Bilke, L., \& Hertel, G. (2015). A meta-analysis on gender differences in negotiation outcomes and their moderators. Psychological Bulletin, 141(1), 85-104. https://doi.org/10.1037/a0038184

Mazei, J., Nohe, C., \& Hüffmeier, J. (2017). Homemaking or breadwinning? Gender differences in negotiation as explained by women's and men's domestic roles. Unpublished presentation at the 30th conference of the International Association for Conflict Management (IACM).

Preacher, K. J., \& Selig, J. P. (2012). Advantages of Monte Carlo confidence intervals for indirect effects. Communication Methods and Measures, 6(2), 77-98. https://doi.org/10.1080/19312458.2012.679848

Rubin, J. Z., \& Brown, B. R. (1975). The social psychology of bargaining and negotiation. New York, NY: Academic Press.

Rudman, L. A., \& Mescher, K. (2013). Penalizing men who request a family leave: Is flexibility stigma a femininity stigma? Journal of Social Issues, 69(2), 322-340. https://doi.org/10.1111/josi.12017

Rudman, L. A., Moss-Racusin, C. A., Phelan, J. E., \& Nauts, S. (2012). Status incongruity and backlash effects: Defending the gender hierarchy motivates prejudice against female leaders. Journal of Experimental Social Psychology, 48(1), 165-179. https://doi.org/10.1016/j.jesp.2011.10.008

Selig, J. P., \& Preacher, K. J. (2008, June). Monte Carlo method for assessing mediation: An interactive tool for creating confidence intervals for indirect effects [Computer software]. Retrieved December, 17, 2020, from http://quantpsy.org/

Shan, W., Keller, J., \& Joseph, D. (2019). Are men better negotiators everywhere? A meta-analysis of how gender differences in negotiation performance vary across cultures. Journal of Organizational Behavior, 40(6), 651-675. https://doi.org/10.1002/job.2357

Small, D. A., Gelfand, M. J., Babcock, L., \& Gettman, H. (2007). Who goes to the bargaining table? The influence of gender and framing on the initiation of negotiation. Journal of Personality and Social Psychology, 93(4), 600-613. https://doi.org/10.1037/0022-3514.93.4.600

Stevens, K., \& Whelan, S. (2019). Negotiating the gender wage gap. Industrial Relations, 58(2), 141188. https://doi.org/10.1111/irel.12228

Stuhlmacher, A. F., \& Linnabery, E. (2013). Gender and negotiation: A social role analysis. In $\mathrm{M}$. Olekalns, \& W. Adair (Eds.), Handbook of research on negotiation (pp. 221-248). London: Edward Elgar.

Stuhlmacher, A. F., \& Walters, A. E. (1999). Gender differences in negotiation outcome: A meta-analysis. Personnel Psychology, 52(3), 653-677. 
https://doi.org/10.1111/j.1744-

6570.1999.tb00175.x

Sutton, R. I., \& Staw, B. M. (1995). What theory is not. Administrative Science Quarterly, 40(3), 371384. https://doi.org/10.2307/2393788

Walters, A. E., Stuhlmacher, A. F., \& Meyer, L. L.

(1998). Gender and negotiator competitiveness: A meta-analysis. Organizational Behavior and Human Decision Processes, 76(1), 1-29. https://doi.org/10.1006/obhd.1998.2797

Whetten, D. A. (1989). What constitutes a theoretical contribution? Academy of Management Review, 14(4), 490-495. https://doi.org/10.5465/amr.1989.4308371

Williams, J. C., Blair-Loy, M., \& Berdahl, J. L. (2013). Cultural schemas, social class, and the flexibility stigma. Journal of Social Issues, 69(2), 209-234. https://doi.org/10.1111/josi.12012

Wood, W., \& Eagly, A. H. (2002). A cross-cultural analysis of the behavior of women and men: Implications for the origins of sex differences. Psychological Bulletin, 128(5), 699-727.

https://doi.org/10.1037/0033-2909.128.5.699

Wood, W., \& Eagly, A. H. (2012). Biosocial construction of sex differences and similarities in behavior. In J. M. Olson, \& M. P. Zanna (Eds.), Advances in experimental social psychology (Vol.46, pp. 55123). Burlington, MA: Academic Press. https://doi.org/10.1016/B978-0-12-3942814.00002-7

Yzerbyt, V., Muller, D., Batailler, C., \& Judd, C. M. (2018). New recommendations for testing indirect effects in mediational models: The need to report and test component paths. Journal of Personality and Social Psychology, 115(6), 929-943. http://dx.doi.org/10.1037/pspa0000132 